\title{
Economic burden of illness from pesticide poisonings in highland Ecuador
}

\author{
Donald C. Cole, ${ }^{1}$ Fernando Carpio, ${ }^{2}$ and Ninfa León ${ }^{3}$
}

Active surveillance of acute pesticide poisonings in a potato-growing region of highland
Ecuador during 1991-1992 uncovered a rate of 171/100 000, due predominantly to occupa-
tional exposures to organophosphate and carbamate pesticides. Occupational exposure among
agricultural workers was the most common reason for poisoning (32 male workers and 1
female worker, out of a total of 50 cases). Of these 33 cases, 28 of them reported pesticide
application as the work task just prior to poisoning, with over $80 \%$ citing the use of World
Health Organization Hazard Category I pesticides. The suicide rate of $17.1 / 100000$ and the
overall mortality rate of 20.5/100 000 that we found are among the highest reported anywhere
in the world. At the exchange rates prevailing at that time, median costs associated with
these poisonings were estimated as follows: public and social security health care direct costs of
US\$ 9.85/case; private health costs of US\$ 8.33/case; and lost-time indirect costs of US\$ $8.33 /$
agricultural worker. Each one of those costs was over five times the daily agricultural wage,
which was then about US\$ 1.50. Further costing of pesticide poisonings should be carried out
in other settings to provide appropriate information for decisions about pesticide use. In addi-
tion, integrated pest management should be further evaluated as an appropriate technology to
reduce the economic burden of illness from pesticide poisonings in developing countries.

Pesticides, economics, and health have been intimately related since the inception of pesticide use centuries ago for crop protection and, more recently, for human disease vector control. Agricultural productivity and international trade have dominated the economic discussions, but there is a growing concern about negative "ex-

\footnotetext{
1 McMaster University, Department of Clinical Epidemiology and Biostatistics, and Institute for Work \& Health, Toronto, Ontario, Canada. Send correspondence to: Donald C. Cole, Institute for Work \& Health, 250 Bloor St. E., Ste. 702, Toronto, Ontario, Canada M4W 1E6; telephone: (416) 9272027, extension 2166; fax: (416) 927-4167; e-mail: dcole@iwh.on.ca

2 National University of Ecuador and Ecuadorian Institute for Social Security, Occupational Disease Section, Quito, Ecuador.

3 Fundación NUESTRA, Quito, Ecuador.
}

ternalities" of agricultural pesticide use (1). Among these externalities, costs associated with human health impacts may be particularly important in the developing world, given that the majority of pesticide poisonings are thought to occur in these regions (2). Information on the economic burden of illness associated with pesticide use could help with the economic justifications of health and agricultural programs aimed at poisoning surveillance or prevention in the fiscally constrained environment of developing countries (3).

Several approaches have been taken to estimating an economic burden of illness associated with pesticide poisoning in developing nations. Building on occupational pesticide intoxication and medical cost data in Costa Rica from the National University's Pesticide Program and the National Insurance Institute (4), Jansen et al. estimated temporary disability and medical treatment costs for wage laborers, with extrapolations to small farmers, based on pesticide use profiles. ${ }^{4}$ Mexican researchers interviewed agricultural producers and medical personnel to arrive at estimates of the numbers of poisoning cases and the resulting expenses due to treatment, transport to and from health care facil-

\footnotetext{
4 Jansen H, Uytewaal E, Stoorvogel JJ. Health costs and pesticide use in the Atlantic zone of Costa Rica. In: Book of Abstracts, International Conference on Pesticide Use in Developing Countries: Impact on Health and Environment. February 23-28, 1998, San José, Costa Rica. p.166.
} 
ities, and lost workdays. ${ }^{5}$ Similarly, Castillo et al. estimated the direct health care costs and the indirect costs of time off work because of acute poisonings in Nicaragua. ${ }^{6}$

An opportunity for health researchers to document costs of pesticide poisoning associated with regular agricultural use of pesticides resulted from the interest of the Rockefeller Foundation and of the centers of the Consultative Group on International Agricultural Research (CGIAR) to assess the sustainability of pesticide use among agricultural producers. Research in the Philippines (5) was followed by our project in Ecuador with the International Potato Center, which combined research on agricultural production, environmental contamination, and human health impacts (6). Here we report on the design, implementation, and results from incorporating information relevant to costs into an active poisoning surveillance system.

\section{METHODS}

The surveillance area for our research in Ecuador was the canton of Montúfar, in the northern province of Carchi, chosen by our agricultural production research colleagues for its large number of potato producers. Montúfar had a population in 1991 estimated at 29204 , according to the Ecuadorian National Statistics Institute. The canton's population is primarily rural, raising potatoes, grains, and dairy cattle. Montúfar's main town is San Gabriel.

Of the adult labor force in 1991, $34 \%$ were small agricultural produc-

\footnotetext{
5 Alvarado J, Drucker A, Gonzalez R, Crowder B, Rubio O. Economic valuation of the health impact of agrochemical use in Yucatán, México. In: Book of Abstracts, International Conference on Pesticide Use in Developing Countries: Impact on Health and Environment. February 23-28, 1998, San José, Costa Rica. p. 164.

6 Castillo C, Appel J. Estimación de los costos económicos causados por las intoxicaciones laborales agudas con plaguicidas en el occidente de Nicaragua [unpublished report]. Managua: Programa de Uso Seguro y Racional de Plaguicidas, CARE Nicaragua; 1990.
}

ers, with another $17 \%$ agricultural workers (7). Literacy was estimated at $86 \%$ in 1982 , and the average number of years of schooling attended at five. According to the existing passive reportable disease system, Carchi had the highest provincial incidence of pesticide poisonings for Ecuador in 1988: 21/100 000 (8).

To begin our active pesticide poisoning surveillance project, we hired a field physician (general practitioner) to live in San Gabriel and work closely with the agricultural technicians hired by our agricultural production research collaborators.

We identified health practitioners in private practice, in the Ministry of Health $(\mathrm{MOH})$ public hospital, in the two $\mathrm{MOH}$ health centers, and in three Ecuadorian Institute for Social Security (EISS) health centers. We decided against attempting to coordinate with out-of-canton centers or hospitals because informed local sources indicated that few poisoning cases were attended outside the canton. Formal agreements were established with the $\mathrm{MOH}$ and the EISS to facilitate cooperation and resource sharing. A case report form was developed based on international protocols (9) and forms from other countries (10), to be completed by health personnel and handed to our project's field physician. The form included sections on health service and practitioner information, patient identification, exposure history (including pesticide application methods and personal protective equipment), symptoms and signs, laboratory tests, hospitalization duration (if applicable), and status on discharge.

A case was defined as someone with a recent history of pesticide exposure and clinical symptoms and signs consistent with pesticide poisoning. The validity of such a case definition depends more on appropriate training and consultation with and feedback to the health professionals applying the definition than do hospital-based systems that have more extensive access to laboratories or treatment options (11). As in other Ecuadorian studies, health personnel indicated a need for training in the recognition, diagnosis, and treatment of pesticide poisoning. ${ }^{7}$ The month before surveillance began in June 1991 a workshop was held to cover those topics and review the use of the case report form. Over $75 \%$ of the invited personnel attended. We provided feedback on preliminary results to participating health personnel in October 1991. A second training workshop was held in March 1992. Although primarily aimed at personnel unable to attend the first workshop, we added additional material, which attracted many of the health personnel who had attended the first workshop. Our project's field physician visited each reporting site weekly to meet with available health practitioners, collect reporting forms, and review pesticide poisoning management.

The 50 cases that were reported from the beginning of June 1991 to the end of May 1992 represent the denominator for many of the following descriptions of the characteristics of the poisoning cases.

From November 1991 on, the field physician also visited patients' homes or workplaces from 2 to 4 weeks after the poisoning episode, making a total of 29 follow-up visits by the end of May 1992. Patients were queried concerning any workdays they had lost and any other costs they, their family, or their employer had incurred because of the poisoning episode. As this questioning was outside the usual clinical care, patients were informed that any information they provided would be kept strictly confidential, that it was solely for research purposes, and that they had complete freedom to refuse to respond. Problems in follow-up were most often logistical, due to inaccurate identification by the health practitioner or to untraceable changes in residence, particularly by farm laborers. No one who was contacted refused to respond.

For estimation of costs, several partially overlapping populations were

\footnotetext{
Shenk M, Ward CR. Environmental assessment of U.S.A.I.D./Ecuador non-traditional agricultura exports project, Phase II [unpublished report]. Maryland, Consortium for International Crop Protection (Project 518-0019, 518-T-058); 1990.
} 
relevant. Public health service treatment costs apply to the 38 cases seen at the San Gabriel hospital and the two seen at $\mathrm{MOH}$ health centers over the course of the year of surveillance. Average daily hospitalization costs were estimated at 25700 sucres and average consultation costs per outpatient visit at 5140 sucres (personal communication, San Gabriel Hospital director). In 3 EISS cases the costs of the outpatient consultations were split between EISS and private copayment by the case and that person's family. The seven cases reported by private physicians had to pay the full consultation fees. Additional private health care costs for all cases included those associated with transport to and from health services, medicines, and other treatment-related expenses. Calculations of workdays and wages lost were based on information from 23 of the 29 followed-up cases. For the six cases not providing wage loss information, we made estimates based on the number of workdays lost and the minimum daily wage then prevailing for a laborer, 1800 sucres, which possibly underestimated the loss for farm owners and more skilled workers. Because the cost distributions were skewed, we cite total and median values rather than means. All costs have been converted to dollars, based on an exchange rate of 1200 sucres $=$ US $\$ 1.00$ at the time of the study.

\section{RESULTS}

Of the 50 cases formally reported during the year of surveillance, a median of 4 cases was reported each month, with a minimum of 2 and a maximum of 10 . The latter number was during the month immediately following the second workshop, demonstrating the importance of motivation of health providers. In addition, 4 more known cases were treated by health providers but with no reports filed. Further, other cases not formally reported may have occurred, given the relative constancy of pesticide use in this region (12) and the wide range we found between the minimum and maximum number of cases reported for the various months.

The pesticides that were reported reflect use patterns known to the agricultural personnel on the project. Mixtures were more common than single products, and carbofuran (29 cases), methamidophos (11 cases), and mancozeb (15 cases) were the most common products. Including 1 case reporting methomyl and 2 cases reporting parathion, over $80 \%$ of all the reported poisonings were with World Health Organization (WHO) Hazard Category I cholinesterase inhibitors (chemically, carbamates and organophosphates) (13). Other products reported were from less hazardous WHO categories (II-IV or 0), including dithiocarbamate fungicides and some pyrethroid insecticides.

The clinical picture reflected the pesticides used, with cholinergic nervous and gastrointestinal symptoms among all the cases with carbamate and organophosphate exposure. Severe clinical manifestations of such poisoning occurred in those who eventually died (6 cases). Skin symptoms were most common among those with fungicide (WHO Categories IV or 0) exposure (10 cases out of 15 fungicide reports). Of the cases, 48 had three or more symptoms and signs, and 37 had five or more symptoms and signs. Only a handful of the symptoms and signs were inconsistent with the effects of the pesticides reported, and removing those symptoms did not result in any cases being excluded.

Out of the total of 50 pesticide poisoning cases, 32 occurred among agricultural working-age males, and 1 occurred in a woman working in agriculture. This result reflects the predominantly gender-based division of labor in the canton, with men taking responsibility for pesticide application. Relatively impermeable personal protective equipment was inadequate, being limited to boots (23 of 33 cases), a plastic sheet on the back (12 of 33), gloves (2 of 33 ), or a poncho (1 of 33 ). Twenty-eight of these 33 cases reported pesticide application as the work task just prior to poisoning, despite that fact that only $13 \%$ of labor days/hectare on the farms involved in the agricultural component of the project were for pesticide application (6).

Of the 17 other pesticide poisoning cases, 9 involved accidental poisoning in agricultural settings, with 8 of those 9 among children. Intentional ingestion of pesticides occurred in the remaining 8 cases, with 6 of the 8 cases occurring among persons 16-20 years old. Five of the intentional and 6 of the accidental cases underwent hospitalization, versus 8 of the occupational cases. Five of 8 intentional cases died, while only 1 accidental and no occupational cases died. Based on the estimated population of the canton of Montúfar, the resulting overall pesticide-related mortality rate was 20.5/100 000, with 17.1 suicide deaths/100 000. After treatment, about half of all accidental and occupational cases discharged still manifested symptoms and signs of poisoning.

Among 15 cases undergoing hospitalization (data missing on 4 cases: 1 intentional, 1 accidental, and 2 occupational), the median length of hospital stay was 2 days and the total hospital days, 33 days, with total estimated costs of US\$ 707. For those 28 nonhospitalized cases that attended EISS and $\mathrm{MOH}$ health centers or only had outpatient treatment at the hospital, total outpatient consultation costs were estimated at US\$120. The total figure of US\$ 827 provides a rough estimate of the overall annual public and social security health care costs, with a median of US\$ 9.85 per case.

Among the private direct costs for outpatient treatment reported by follow-up cases, the majority of expenses were attributable to medicines, followed by costs of transportation to and from health services and of medical consultations (Table 1). Other costs included family lodging, meal costs, and laboratory costs. Median private costs among the 22 of 29 cases followed up who reported such expenditures were US\$ 8.33 per case. Among the 29 follow-up cases, 23 youth and adults lost a total of 99 workdays, resulting in an estimated overall wage/income loss of approximately US\$249.88, with a median of US\$ 8.33 (Table 2). 
TABLE 1. Private health care and related costs (in US\$) reported by pesticide poisoning cases, Montúfar, Carchi, Ecuador, 1991-1992

\begin{tabular}{llllll}
\hline & Medicines & Transportation & Consultations & Other & Total \\
\hline Number of cases & & & & & \\
with cost & 21 & 16 & 10 & 6 & 22 \\
Range in costs & $\$ 0-\$ 46.25$ & $\$ 0-\$ 13.33$ & $\$ 0-\$ 25.00$ & $\$ 0-\$ 15.00$ & $\$ 0-\$ 59.58$ \\
Median cost & $\$ 5.83$ & $\$ 0.83$ & $\$ 0$ & $\$ 0$ & $\$ 8.33$ \\
$\quad$ Total costs & $\$ 257.24$ & $\$ 89.50$ & $\$ 72.25$ & $\$ 37.67$ & $\$ 456.66$ \\
\hline
\end{tabular}

a Based on 29 cases visited in follow-up, identified through active surveillance, November 1991-May 1992.

TABLE 2. Reported workdays and income (US\$) lost by pesticide poisoning cases, Montúfar, Carchi, Ecuador, 1991-1992a

\begin{tabular}{|c|c|c|c|c|c|}
\hline \multirow[b]{2}{*}{ Occupation } & \multirow[b]{2}{*}{ Cases } & \multicolumn{2}{|c|}{ Number of workdays lost } & \multicolumn{2}{|c|}{ Wage/Income loss } \\
\hline & & Median & Total & Median & Total \\
\hline \multicolumn{6}{|l|}{ Agriculture } \\
\hline \multicolumn{6}{|l|}{ Laborers } \\
\hline Temporary & 6 & 3 & 33.5 & $\$ 12.19$ & $\$ 76.88$ \\
\hline Regular & 5 & 2 & 14 & $\$ 6.25$ & $\$ 36.08$ \\
\hline Family members & 3 & 5 & 14 & $\$ 12.00$ & $\$ 27.00$ \\
\hline Owners & 7 & 3 & 21.5 & $\$ 10.4$ & $\$ 82.42$ \\
\hline Nonagriculture & 1 & 15 & 15 & $\$ 25.00$ & $\$ 25.00$ \\
\hline Unknown & 1 & 15 & 1 & $\$ 2.50$ & $\$ 2.50$ \\
\hline Total/Overall & 23 & 3 & 99 & $\$ 8.33$ & $\$ 249.88$ \\
\hline
\end{tabular}

a Based on 23 cases with data of the 29 cases visited in follow-up, identified through active surveillance, November 1991-May 1992.

Combining private health care costs and wage/income loss, median overall private costs would be approximately $\$ 17 /$ case. This was over 11 times the daily agricultural wage among the predominantly agricultural population.

\section{DISCUSSION}

The pesticide poisoning profile for this highland Andean canton is comparable to that observed in virtually every other agricultural area of the developing world that has instituted an active surveillance program. Among these characteristics are multiple-pesticide "cocktail" applications (14), limited use of effective personal protective equipment $(10,15)$, and high suicide mortality due to pesticides among agricultural populations (16-18). Such findings support the need for other levers, such as economic impacts, to bring about changes in agricultural pesticide use practices and poisoning prevention. As we have demonstrated in this research, information on economic impacts could be obtained without a great increase in effort by those involved in an active surveillance program.

Nevertheless, the health care utilization associated with such poisoning episodes appears to be minimal in most rural health programs. For example, in our study area in Ecuador, several thousand emergency visits and tens of thousands of clinical consultations are recorded each year (19). In contrast, poisoning case rates have continued to be only about 50 per year (20).

Estimated costs to health services in Montúfar are comparable to those that Castillo et al. reported for Nicaragua. Using more detailed information on the medicines used in treatment and estimates of clinical observation times, the Nicaragua investigators calculated a mean treatment cost of US\$ 11.90 per case. That was similar in magnitude to what we observed in Ecuador, especially given the fact that the Nicaragua researchers used means rather than the medians we used. Based on interviews with poisoning cases, family members, and employers, the private costs in Nicaragua for food, transport, medicines, and replacement of labor were estimated to be US\$ 10.36 per case, again similar to the figure we found in our study. In a rural household budget survey conducted in Ecuador during the late 1970s, personal health expenditures in the highland regions occupied between 5.1\% and $7.7 \%$ of total farming household expenditure. ${ }^{8}$ Over-the-counter drugs, medicines, and vitamins accounted for between $75 \%$ and $80 \%$ of this amount, while outpatient visits accounted for about another $10 \%$. Pesticide poisoning may contribute to these household health expenditures.

Nicaraguan occupational poisoning cases, according to Castillo et al., were absent from work an average of 7 days per poisoning and had wage losses estimated at US $\$ 4.07$ per case, likely reflecting the lower average wage rate of US\$ $0.75 /$ day for Nicaraguan agricultural laborers. The Nicaragua researchers also found that family members spent an average of 14.7 hours providing sick care for each poisoning case.

In other countries, estimates have been made of combined costs. In Costa Rica, these expenses were between US\$ 75 and US\$ 100 per case in total costs to the health system, the enterprise, and the workers or small farmers involved, according to Jensen et al. Inclusion of enterprise costs, higher relative wage rates, and the more severe poisonings found through the passive surveillance system all likely contribute to these higher cost estimates. Using a different approach in the Mexican state of Yucatán, Alvarado et al. estimated that poisoning cases cost the equivalent of $1.9 \%$ of the value of the gross agricultural product of the cultivated area. In the agricul-

\footnotetext{
8 Immink MDC. Food and health expenditure patterns in urban and rural Ecuador: analysis of household budget survey data [unpublished report]. Quito, Ecuador: U.S. Agency for International Development, AID/DSPE-C-0053; 1984.
} 
tural production component of the research program in Montúfar, which focused on 40 cooperating farms, the majority of the farms were less than 10 hectares in size and had average labor costs estimated at US $\$ 420 /$ hectare of potatoes, and average net revenues were US\$ 437/ha (6). These average figures mask the fact that 7 of the 40 cooperating farms lost money during the 1990-1992 study period.

Our and other researchers' estimates of costs associated with pesticide poisoning are likely to be underestimates, for a variety of reasons. First, not all poisoning cases seek care. Many persons may not know the symptoms of pesticide poisoning; this was true for $44 \%$ of small farmers and farm workers who regularly used pesticides in a 1984 survey in nine provinces of highland Ecuador (21). Even with active surveillance data, at least a third of poisoning cases did not seek health care in rural Nicaragua (22). In a cross-sectional survey done in Ecuador in parallel with this study, household members and employees of 40 farms reported seeking clinical care for only $9 \%$ of poisoning episodes (12). Second, poisoning sequelae have not been fully identified. One of the noteworthy findings of our study in Carchi was the persistence of symptoms following discharge from the hospital. Previous poisoning is one of the predictors of peripheral neurological effects (23). Third, other costs have likely been overlooked, as has been argued for the social consequences of injuries and illnesses elsePimental D, Lehman $\mathrm{H}$, eds. The pesticide
question: environment, economics, and ethics. New York: Chapman Hill; 1992.

2. World Health Organization. Public health impact of pesticides used in agriculture: report of the WHO/UNEP Working Group. Geneva: WHO; 1990.

3. Mills A. Economic evaluation of health programmes: application of the principles in developing countries. World Health Stat Q 1985; 38(4):368-382.

4. Wesseling C, Castillo L, Elinder CG. Pesticide poisonings in Costa Rica. Scand J Work Environ Health 1993(4):227-235. where. ${ }^{9}$ These additional costs would include time for parents taking care of poisoned children, funeral expenses for the deceased, and lost time for the mourners. Better estimates of these kinds of costs could also come from considering the lost earnings from pesticide poisoning sequelae or from death, as is done in environmental assessment processes in developed countries. Creative forms of full-costing of pesticide use in human terms need to be further developed for the debate over the economics of pesticide use and regulation (24).

Better documentation of the economic burden of illness, developed from different viewpoints, could serve as a lever on different sectors of society. For example, education programs among farm families could discuss the tradeoffs between the costs of poisonings and the added costs of less toxic compounds or of personal protective equipment. Farmers with slim profit margins might be particularly receptive to this information. Cost and productivity data could encourage agricultural personnel to reorient production and apply integrated pest management strategies to reduce agricultural pesti-

\footnotetext{
9 Dembe AE. The social consequences of occupational injuries and illnesses. Invited conference paper, $\mathrm{Na}-$ tional Institute for Occupational Safety and Health conference, Functional, Economic and Social Outcomes of Occupational Injuries and Illnesses: Integrating Social, Economic and Health Services Research, June 13-15, 1999, Denver, Colorado.
}

cide use (25). Among health service managers, health care utilization costs may appear to be minimal, except for hospitalization expenses. Nevertheless, in settings with intensive care units, these costs may be of considerable importance. Demonstrating these poisoning costs to companies that produce pesticides could spur the companies into funding independent hazard auditor programs that would monitor the health impacts of pesticide products and application equipment in the developing world (26). Finally, including cost data collection in surveillance systems and generating data on the economic burden of illness could help mobilize the health sector to become involved in policy decisions on pesticide use and poisoning prevention, such as is now being done in Central America (27).

Acknowledgements. We would like to thank the Rockefeller Foundation, through the International Potato Center, for financial support for the research, as well as the Canadian EcoResearch Council for salary support to Donald C. Cole during the writing of this paper. Our thanks also go to John Antle, University of Montana, for conceiving the sustainability project; to health practitioners in San Gabriel for collaboration in reporting and followup; to Victor Bravo for work as the field physician; to Jaime Andrade for Ecuadorian data base management; and to Charles Crissman of the International Potato Center for logistic support.

\section{REFERENCES}

5. Rola AC, Pingali PL. Pesticides, rice productivity, and farmers' health. An economic assessment. Manila, Philippines, International Rice Research Institute \& Washington, D.C., World Resources Institute; 1993.

6. Crissman CC, Antle JM, Capalbo SM, eds. Economic, environmental, and health tradeoffs in agriculture: pesticides and the sustainability of Andean potato production. Dordrecht/Boston/ London: Kluwer Academic Publishers; 1998

7. Breilh J, Granda E, Campaña A, Yépez J, Páez $\mathrm{R}$, Costales P. La cuantificación del deterioro. In: Breilh J, Campaña A, Granda E, Páez R, eds. Deterioro de la vida: un instrumento para análisis de prioridades regionales en lo social y la salud. Quito: Corporación Editora Nacional, 1990. Pp. 171-490. (Biblioteca de Ciencias Sociales Volumen 28).

8. Carpio F. La prevención sanitaria de la intoxicación crónica por plaguicidas. In: Memorias del Seminario Nacional Sobre Plaguicidas. Quito, Ecuador: Fundación Natura/AFEME/ Ministerio de Salud; 1989. Pp. 25-42

9. World Health Organization, European Regional Office. Organophosphorus pesticides: an epidemiologic study. Copenhagen: WHO European Regional Office; 1987. (Environmental Health Series, no. 22). 
10. Cole DC, McConnell R, Murray DL, Pacheco Anton F. Pesticide illness surveillance: the Nicaraguan experience. Bull Pan Am Health Organ 1988;22(2):119-132.

11. McConnell R, Hruska AJ. An epidemic of pesticide poisoning in Nicaragua: implications for prevention in developing countries. Am J Public Health 1993;83(11):1559-1562.

12. Crissman CC, Cole DC, Carpio F. Pesticide use and farm worker health in Ecuadorian potato production. Amer J Agr Econ 1994;76: 593-597.

13. International Programme on Chemical Safety. The WHO recommended classification of pesticides by hazard and guidelines to classification 1992-1993. Geneva: United Nations Environment Programme, International Labour Organization, World Health Organization; 1992. (WHO/IPCS/92.14).

14. Jeyaratnam J, De Alwis Seneviratne RS, Copplestone JF. Survey of pesticide poisoning in Sri Lanka. Bull World Health Organ 1982; 60(4):615-619.

15. Kishi M, Hirschhorn N, Djajadisastra M, Satterlee LN, Strowman S, Dilts R. Relationship of pesticide spraying to signs and symptoms in Indonesian farmers. Scand J Work Environ Health 1995;21(2):124-133.
16. Berger LR. Suicides and pesticides in Sri Lanka. Am J Public Health 1988;78:826-828.

17. Maniam T. Suicide and parasuicide in a hill resort in Malaysia. Br J Psychiatry 1988;153: 222-225.

18. Bödeker W. Suicidal pesticide poisoning. World Health Forum 1991;12(2):208-209.

19. Ecuador, Ministerio de Salud Publica, División Nacional de Estadística. Informe anual de establecimientos de salud, 1997. Quito: MSP; 1998.

20. Ecuador, Ministerio de Salud Publica, División Nacional de Epidemiologia. Estadísticas de enfermedades epidemiológicas, Ecuador 1990-1997. Quito: MSP; 1998.

21. Grieshop JI, Winter DM. Agricultural pesticide accidents and prevention in Ecuador. Accid Anal Prev 1989;21(4):394-398.

22. Keifer M. Self-reported pesticide poisonings in Leon, Nicaragua: report of a survey [MPH thesis]. Seattle, Washington: University of Washington; 1989.

23. Cole DC, Carpio F, Julian J, Leon N. Assessment of peripheral nerve function in an Ecuadorian rural population exposed to pesticides. J Toxicol Environ Health 1998;55(2):77-91.

24. Zilberman D, Schmitz A, Casterline G, Lichtenberg E, Siebert JB. The economics of pesti- cide use and regulation. Science 1991;253: 518-522.

25. Kenmore P. Indonesia's integrated pest management - a model for Asia. Manila, Philippines: Food and Agriculture Organization; 1991.

26. Loevinsohn ME. Improving pesticide regulation in the Third World: the role of an independent hazard auditor. In: Forget G, Goodman T, de Villiers A, eds. Impact of pesticide use on health in developing countries: proceedings of a symposium held in Ottawa Canada, 17-20 September 1990. Ottawa, Ontario: International Development Research Centre; 1993. p. 166-177.

27. Keifer M, Murray DI, Amador R, et al. Solving pesticide problems in Latin America: a model for health-sector empowerment. New Solutions 1997;7(2):26-31.

Manuscript received on 12 October 1999; accepted for publication on 9 May 2000.

RESUMEN Durante el período 1991-1992, la vigilancia activa de las intoxicaciones agudas por pesticidas en una región montañosa de Ecuador cultivadora de papas reveló una tasa de 171/100 000, debido, sobre todo, a la exposición ocupacional a pesticidas organofosforados y carbamatos. La exposición ocupacional de los trabajadores agrícolas fue la causa más frecuente de intoxicación (32 trabajadores del sexo masculino y 1 del sexo femenino, de un total de 50 casos). De estos 33 casos, 28 informaron que su trabajo inmediatamente antes de la intoxicación consistía en la aplicación de pesticidas, y más de $80 \%$ mencionaron el uso de pesticidas incluidos en la Categoría de Riesgo I de la Organización Mundial de la Salud. La tasa de mortalidad global relacionada con los pesticidas, de 20,5/100 000, y la tasa de suicidios de 17,1/100 000 se encuentran entre las más elevadas de todo el mundo. A las tasas de cambio existentes entonces, se estimaron los siguientes costes medianos asociados a estas intoxicaciones: costes directos por atención sanitaria pública y de la seguridad social, US $\$ 9,85 /$ caso; costes por atención sanitaria privada, US $\$ 8,33 /$ caso, y costes indirectos por tiempo de trabajo perdido, US\$ 8,33/trabajador agrícola. Cada uno de estos costes fue más de cinco veces superior al salario agrícola diario, que entonces era de aproximadamente US\$1,50. Con el fin de obtener información adecuada para la toma de decisiones acerca del empleo de pesticidas serían necesarias nuevas evaluaciones de los costes de las intoxicaciones por pesticidas en otros contextos. Además, se debería evaluar de nuevo el control integral de las plagas como una tecnología adecuada para reducir la carga económica de las intoxicaciones por pesticidas en los países en desarrollo. 